\title{
Floral nectar secretion and ploidy in Brassica rapa and $B$ napus (Brassicaceae). I. Nectary size and nectar carbohydrate production and composition *
}

\author{
AR Davis ${ }^{1}$, VK Sawhney ${ }^{1}$, LC Fowke ${ }^{1}$, NH Low ${ }^{2}$ \\ 1 Department of Biology; \\ 2 Department of Applied Microbiology and Food Science, \\ University of Saskatchewan, Saskatoon, Saskatchewan, S7N OWO Canada
}

(Received 9 May 1994; accepted 3 August 1994)

\begin{abstract}
Summary - Haploid $(n=10)$, diploid $(2 n=20)$ and tetraploid $(4 n=40)$ lines of Brassica rapa (syn campestris), and a line of allotetraploid $(4 n=38) B$ napus, were examined to determine whether ploidy can influence nectar production. Flowers of all lines developed functional nectaries. Overall, nectar carbohydrates consisted almost exclusively of glucose and fructose, present in quantities slightly in favour of the former. Sucrose was detected in only $15 \%$ of samples, usually in trace amounts. For all levels of ploidy, $95 \%$ of total nectar carbohydrate per flower was expelled from the lateral (inner) pair of glands. These glands were directly supplied with phloem alone, whereas the median (outer) glands, which were poor nectar yielders, usually did not receive any vascular supply. Haploids only produced $30 \%$ as much nectar carbohydrate as $2 n$ and $4 n$ lines of $B$ rapa, which in turn exuded only $44-50 \%$ of the average quantity of nectar carbohydrate released by $B$ napus. A linear regression $(r=0.803)$ of mean lateral-nectary volume on average total nectar-carbohydrate per flower was determined for all plants of $B$ rapa, but this was modified $(r=0.445)$ when data for $B$ napus were included. In all lines, opportunity exists for selection for high nectar-carbohydrate production. Plants yielding the most floral nectar carbohydrate had high frequencies $(80-95 \%)$ of lateral glands that were symmetrical and of uniform size within a flower.
\end{abstract}

\section{Brassica rapa / Brassica napus / floral nectar / nectar carbohydrates / nectary / ploidy}

\section{INTRODUCTION}

Due primarily to the pioneering efforts of the late Dr A Maurizio, the influence of ploidy on floral nectar production by beevisited plants has already been investigated in 4 plant families. She determined nectar yields and nectar-sugar concentrations for up to 4 species each in the Campanulaceae, Fabaceae, Lamiaceae and Solanaceae (Maurizio, 1954, 1956). Except for recent investigations on Nicotiana spp (Cocucci and Galetto, 1992), other studies on ploidy and nectar secretion have centred on 2 species, Trifolium

* This paper is dedicated to the memory of Dr Anna Maurizio, founding member of the International Commission for Plant-Bee Relationships (formerly the International Commission for Bee Botany). 
hybridum (Skirde, 1963) and especially $T$ pratense (Paatela, 1962; Valle et al, 1962; Skirde, 1963; Bond, 1968; Eriksson, 1979; Fussell, 1992). Most of these studies have compared nectar production of plants which are naturally diploid with those which are polyploid (triploid, tetraploid and octaploid); haploids have not been considered.

Nectar produced by flowers of Brassica spp is a well-known attractant to potential insect pollinators (Eisikowitch, 1981; Murrell and Nash, 1981; Fries and Stark, 1983; Williams, 1985; Mohr and Jay, 1988) and represents a large source of honey worldwide (Crane, 1975). This study was conducted to determine any effect that differences in ploidy level might have on nectary size and nectar-carbohydrate production, concentration and composition, in the Brassicaceae. Haploid, diploid and tetraploid plants of $B$ rapa (syn campestris), and allotetraploid plants of the genetically related $B$ napus, were compared.

\section{MATERIALS AND METHODS}

\section{Plant material}

Haploid $(n=10)$, diploid $(2 n=20)$ and tetraploid $(4 n=40)$ plants of $B$ rapa, and plants of $B$ napus $(4 n=38,2 n+2 n=20$ from $B$ rapa +18 from $B$ oleracea $=38$ ), were grown under controlled climatic conditions (16 h light/8 h dark, $150 \mu \mathrm{mol} / \mathrm{m}^{2} \mathrm{~s}, 20-22^{\circ} \mathrm{C}$ ) in a greenhouse (haploids) or in growth chambers. Except for the haploid lines, all plants were derived from seed of the 'rapid-cycling' forms of Brassica (Williams and Hill, 1986), characterised by a shorter time to flowering than conventional lines. Plants of different ploidy were not from the same genetic background. Potential insect pollinators were absent.

\section{Nectar collection}

Eighteen to 22 flowers were sampled for nectar from each of 4 plants (numbered 1-4) per ploidy level. The haploids were an exception; only 3 plants $(5-49,5-63,5-93)$ were available for nectar studies. Over several days, fully-open flowers, $24 \mathrm{~h}$ after anthesis, were excised and their nectar immediately collected using filter-paper wicks (McKenna and Thomson, 1988). To enhance collection of all of the viscous nectar present, tips of wicks were initially dipped in pure distilled water and the process of withdrawing nectar at the flower base using the wicks was viewed through a dissecting microscope. Commonly, more than one wick was required per nectar droplet.

Nectar from each of the heavily secreting lateral glands (Davis et al, 1986) of 5 additional, identical flowers from these plants was collected using Drummond Microcaps ( $1 \mu \mathrm{l})$ and its solute concentration immediately assessed using a hand-held refractometer $(40-80 \%$, Bellingham and Stanley, Tunbridge Wells, UK). Even though this instrument had been modified by the manufacturer to accomodate minute volumes, the extremely low quantities of viscous nectar available from lateral glands of the haploid plants, unfortunately, could not be analysed for concentration. After temperature correction to $20.0^{\circ} \mathrm{C}$, concentrations of nectar solutes were calculated as $\mathrm{g} / \mathrm{ml}$ from $\mathrm{g} / \mathrm{g}$ using the formula for conversion of refractometer readings (Bolten et al, 1979; Búrquez and Corbet, 1991).

\section{Nectar carbohydrate analysis}

From the filter-paper wick collections of nectar (above), a subsample of 16 floral exudates per plant was selected at random. After elution from the stored, dry wicks using $0.5-1.0 \mathrm{ml}$ distilled water $\left(3^{\circ} \mathrm{C}\right)$, each nectar sample was filtered, diluted as required and then analysed separately on a Waters 625 metal-free gradient high performance liquid chromatograph. Carbohydrates were separated using a Carbo Pac PA1 (Dionex) pellicular anion exchange column $(4 \times 250 \mathrm{~mm})$. A Waters 712 Wisp autosampler was utilized for analysis; $100 \mu$ l of each sample was injected. Elution of the nectar carbohydrates was accomplished with a mobile phase of $80 \mathrm{mM} \mathrm{NaOH}$ at a flow rate of $1.0 \mathrm{ml} / \mathrm{min}$. The carbohydrates were detected by a pulsed amperometric detector (PAD; Waters Model 464) with a dual gold electrode and triple pulsed amperometry at a sensitivity of $50 \mathrm{~mA}$. The electrode was maintained at the following potentials and durations: $E_{1}=0.05 \mathrm{~V}$ $\left(T_{1}=0.299 \mathrm{~s}\right) ; E_{2}=0.60 \mathrm{~V}\left(T_{2}=0.299 \mathrm{~s}\right) ; E_{3}=$ 
$-0.80 \mathrm{~V}\left(\mathrm{~T}_{3}=0.499 \mathrm{~s}\right)$. The carbohydrates eluting from the column were plotted by a Maxima 820 chromatography work station (Millipore). Peak areas were compared to known standards. Where individual nectar droplets per flower were analysed separately, the total nectar carbohydrate per flower was calculated by summation of those samples.

\section{Determination of nectary volume}

Following nectar collection, 10 of these flowers per plant, chosen randomly, were fixed and processed for scanning electron microscopy (SEM) (Davis et al, 1986). The lateral nectaries (fig 1) were found to produce almost all of a flower's total nectar carbohydrates (see Results). Accordingly, to determine whether a relationship existed between nectar-carbohydrate production per flower and nectary size, volumes of lateral glands were determined from SEM images (Davis et al, submitted).

\section{Examination of sections of nectary tissue using light microscopy}

After their nectar had been collected, the perianth was removed and several flowers per plant were fixed and dehydrated before embedding in LR White resin (Davis and Gunning, 1992). Sections (1.5 $\mu \mathrm{m}$ thickness) were cut using glass knives on a Reichert Ultramicrotome OmU3, stained with toluidine blue $O$ and then observed and photographed with a Zeiss Axioplan Universal light microscope.

\section{RESULTS}

\section{Nectary location and anatomy}

Regardless of ploidy level, all plants had floral nectaries, which were generally in the normal positions for the genus (Norris, 1941; Clemente Munoz and Hernandez Bermejo, 1978; Davis et al, 1986). In $B$ napus and $B$ rapa, each flower bears 2 pairs of nectaries at the base of the 6 stamens. Each lateral (inner) gland is located internal to the filament base of a short stamen (figs 1,2), whereas each median (outer) gland is found external to the filament bases of the long stamens (figs $1,4,5$ ).

In terms of vasculature, a disparity existed between lateral and median glands within the same flowers. Lateral nectaries received vascular traces of phloem sieve elements that entered the gland bases and were evident throughout the gland interior (figs 2, 3). Median nectaries, however, normally lacked any vascular supply (figs 4,5 ).

\section{Nectar carbohydrate production and concentration}

In the $2 n$ and $4 n$ plants of $B$ rapa, and in $B$ napus, nectar was always available at both lateral nectaries in each of 80-83 flowers taken from 4 plants per ploidy level. Moreover, $94-99 \%$ of these flowers produced

Figs 1-5. Features of the nectaries of nectar-secreting flowers of diploïd $B$ rapa (plant 3). 1. SEM of flower base showing lateral nectary (LN) surrounded by insertion points of long stamens (IS), petals (P) and a short stamen (ss). Two median nectaries (MN) are evident at opposite sides of the flower. Bases of the gynoecium (G) and a lateral sepal (sp) are evident. Scale bar $=0.5 \mathrm{~mm}$. 2. Transverse section through a flower, showing secretory tissue of a lateral nectary delimited by the bases of short (ss) and long (Is) stamens. The arrows indicate the direct supply of phloem to the nectary. Bar $=100$ $\mu \mathrm{m}$. 3. Higher magnification similar to figure 2, illustrating the strands of phloem sieve elements (arrows) found within a lateral nectary. $B a r=50 \mu \mathrm{m}$. 4. Longitudinal section through a crescent-shaped median nectary similar to the left-most gland of figure 1 . Note the lack of a vascular supply in this gland. Long stamens (Is). Bar $=100 \mu \mathrm{m}$. 5. Oblique section through a peg-shaped median nectary like the right-most gland of figure 1, showing the absence of vasculature within the gland. Stoma (arrowhead). Bar = $100 \mu \mathrm{m}$ 

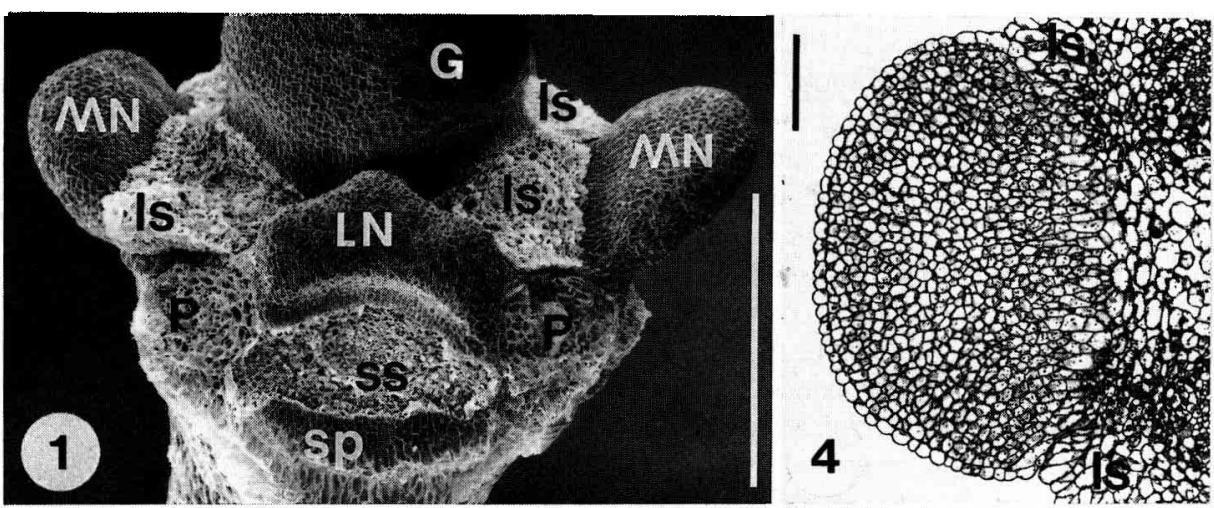

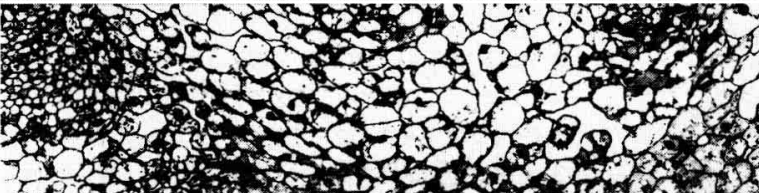

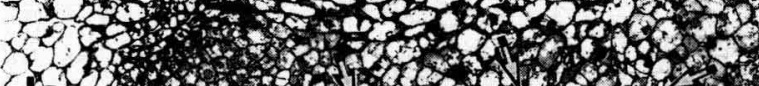

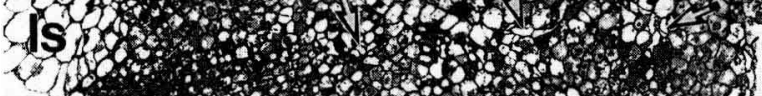
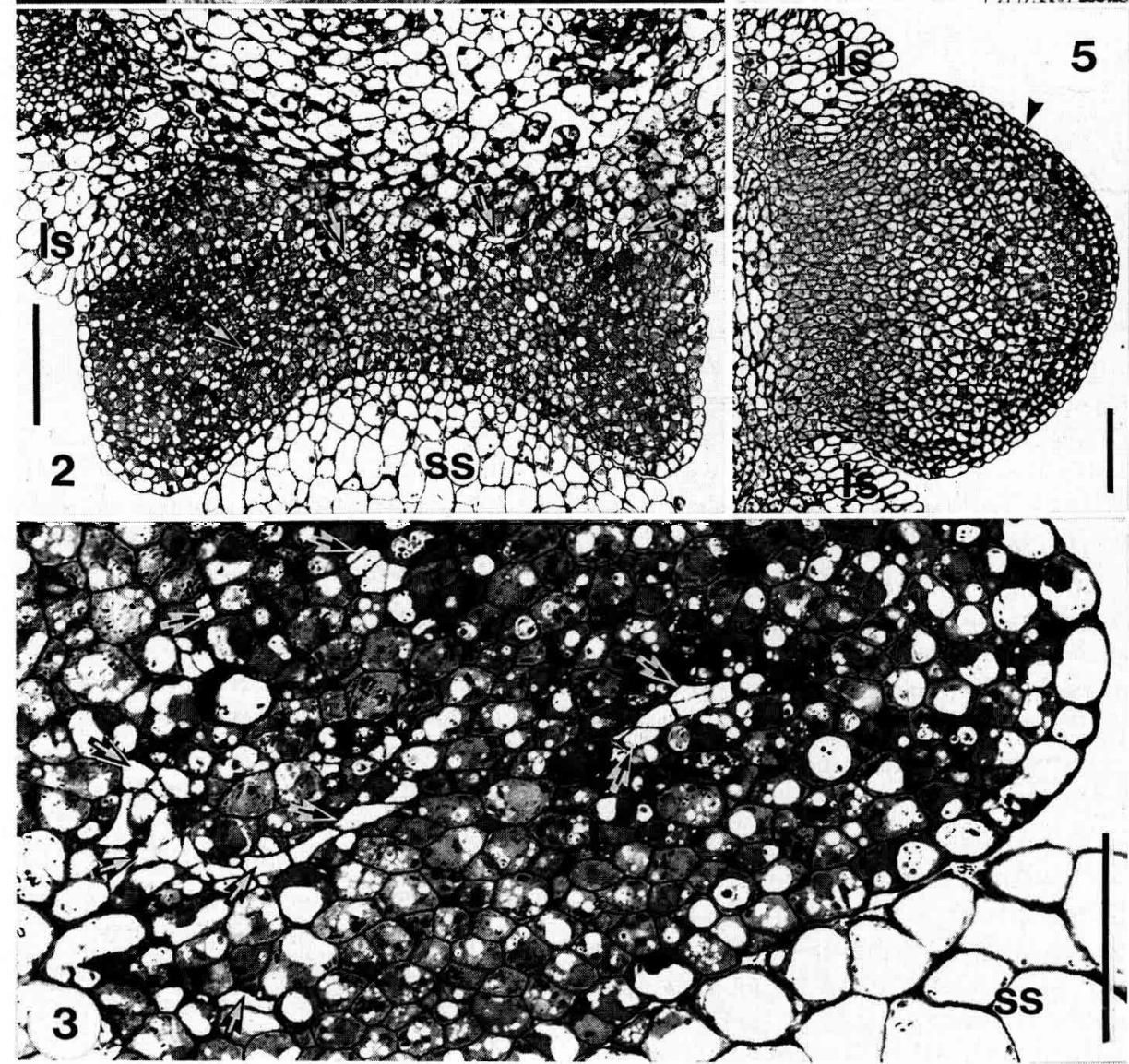
collectable quantities of nectar at both median positions per flower. On the other hand, in the $n$ plants of $B$ rapa, 2 flowers of line 5-49 lacked nectar at 1 lateral gland, and, throughout the $n$ plants, only $45 \%$ of flowers produced nectar at both median nectaries. In fact, in $36 \%$ of flowers, nectar was absent altogether from the median glands. The latter phenomenon was most prevalent in line 5-63, in which 15 of 18 flowers produced nectar only from the lateral nectaries. This situation did not adversely affect the mean nectar-carbohydrate production per flower in line 5-63, which yielded at least as much sugar as the other $n$ lines (fig 6 ).

Plants of each ploidy level and species exhibited variation in total nectar-carbohydrate production per flower, such that significant differences were detected for each (fig 6). Overall, haploid plants produced, on average, only $28-32 \%$ as much nectar carbohydrate as $2 n$ and $4 n$ plants of $B$ rapa (table I). However, total quantities of nectar sugar between the 2 latter lines did not differ significantly (table I). The total amounts of nectar carbohydrate exuded per flower by $2 n$ and $4 n$ plants of $B$ rapa were only $44-50 \%$ of the average quantities produced by $B$ napus (table I).

In the $2 n$ plants of $B$ rapa, and in $B$ napus, these mean weights of nectar carbohydrate accounted for over half of the flower dry weight (table I). In the $n$ and $4 n$ plants of $B$ rapa, the proportion of flower dry weight attributable to nectar sugar was less (table I).

Despite these overall differences in mean nectar-carbohydrate production, the proportion of total carbohydrate per flower that escaped only from the lateral nectaries was high and consistent for all combinations of species and ploidy, about $95 \%$ for each (table I). Similarly, the concentration of nectar solutes collected at the lateral glands was equal for all rapid-cycling lines of Brassica, and usually very similar at both lateral positions within a flower (table II). How- ever, the $4 n$ line of $B$ rapa had significantly greater variation in nectar-solute concentration at lateral locations within a flower, than did $2 n$ plants of $B$ rapa, or $B$ napus (table II).

\section{Nectar-carbohydrate composition}

The nectar carbohydrates of both species of Brassica, regardless of ploidy level, were found to be constant, and consisted almost entirely of glucose and fructose (table III). The quantities of glucose usually slightly exceeded those of fructose, such that the average ratio of the monosaccharides ranged from 1.02 to 1.13 (table III). Only in 2 cases, plants 2 and 4 of diploid $B$ rapa, was the mean ratio of glucose/fructose below unity.

\section{Volume of lateral nectaries and nectar-carbohydrate production}

Just as the study plants displayed considerable variation in mean nectar-carbohydrate production of their flowers, interploidal overlap in size of their lateral nectaries was also evident (fig 7). Plant 4 of $4 n B$ rapa had lateral glands over twice as voluminous as, and plant 2 of the $2 n B$ rapa had glands larger than, any plant of $B$ napus, on average (fig 7). Overall, the average volume of each lateral gland of the $n$ plants of $B$ rapa was significantly lowest, ranging from $25.0-38.3 \%$ of the mean size of nectaries from all other ploidy types. However, despite differences in flower size, the average volume of lateral nectaries did not differ significantly between $B$ napus and $2 n$ and $4 n B$ rapa (Davis et al, submitted).

A regression of mean lateral-nectary volume on average nectar carbohydrate per flower for all plants of the 3 ploidy levels of $B$ rapa took a strongly positive, linear form 


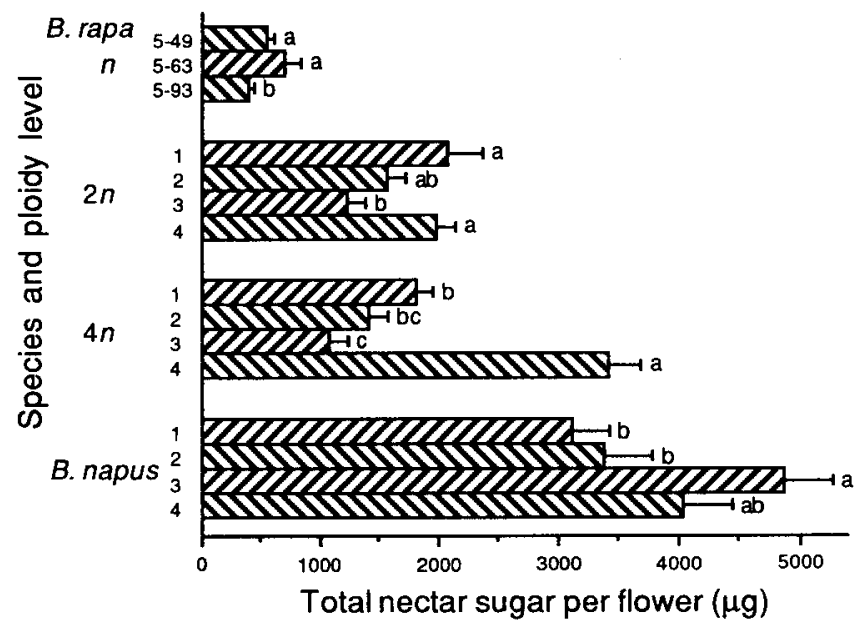

Fig 6. Total nectar carbohydrate per flower (mean \pm SE) in $B$ rapa and $B$ napus, for 3 or 4 plants per ploidy level. Within ploidy groups, plants designated by different letters are significantly different at $P$ $=0.05$, using 2-tailed $t$ tests.

Table I. Relationship between ploidy and nectar-carbohydrate production in $B$ rapa and $B$ napus. Nectar data from 16 flowers per plant were used to comput the following data.

Species Ploidy No level plants

Total per flower $(\mu \mathrm{g})$ $($ mean $\pm S E)$
Nectar carbohydrates

Percentage of total expelled by lateral nectaries (mean $\pm S E$ )
Percentage of flower dry weight

$\begin{array}{lllc}\text { B rapa } & n & 3 & 548.05^{\mathrm{a}} \pm 87.85 \\ & 2 n & 4 & 1711.77^{\mathrm{b}} \pm 196.15 \\ & 4 n & 4 & 1935.52^{\mathrm{b}} \pm 517.72\end{array}$

$93.77^{a} \pm 3.36$

$95.61^{\mathrm{a}} \pm 0.60$

$92.86^{\mathrm{a}} \pm 2.89$

$94.72^{a} \pm 0.89$
33.2

53.0

41.8

56.1

Means in columns followed by different letters are significantly different at $P=0.05$, using 2-tailed $t$ tests.

$(r=0.803)$ (fig 7). The large lateral nectaries of plant 4 of the $4 n B$ rapa, however, carried a disproportionate weighting. When the data for the 4 plants of $B$ napus were combined with the $B$ rapa data, the new regression was still positive and linear, but not as strong ( $r=0.445)$ (fig 7).
Relationships between volume of lateral nectaries and the total nectar carbohydrate per flower within a ploidy level were usually strong $(r>0.84)$ and inverse when nectary size within a flower was expressed as a ratio (fig 8). Although the relationship did not hold for $2 n$ plants of $B$ rapa, plants whose nec- 
Table II. Comparison of solute concentration of nectar from lateral floral nectaries of rapid-cycling lines of Brassica; nectar data from 5 flowers (10 lateral nectaries) per plant were used to comput the following data.

$\begin{array}{lcccc}\text { Species } & \begin{array}{c}\text { Ploidy } \\ \text { level }\end{array} & \begin{array}{c}\text { No } \\ \text { plants }\end{array} & \begin{array}{c}\text { Nectar solute concentration } \\ (g / m /)(\text { mean } \pm S E)\end{array} & \begin{array}{c}\text { Ratio of nectar solute concentration } \\ \text { at lateral locations within a flower } \\ \text { (mean } \pm S E)\end{array} \\ \text { B rapa } & 2 n & 4 & 1.043^{\mathrm{a}} \pm 0.012 & 1.0252^{\mathrm{a}} \pm 0.00302 \\ & 4 n & 3 & 1.034^{\mathrm{a}} \pm 0.002 & 1.0438^{\mathrm{b}} \pm 0.00313 \\ \text { B napus } & 4 n & 4 & 1.058^{\mathrm{a}} \pm 0.008 & 1.0185^{\mathrm{a}} \pm 0.00283\end{array}$

Means in columns followed by different letters are significantly different at $P=0.05$, using 2-tailed $t$ tests.

Table III. Relationship between ploidy and overall nectar carbohydrate composition in $B$ rapa and $B$ napus. Nectar data from 16 flowers per plant were used to comput the following data.

Species Ploidy No
level plants
Nectar carbohydrate

Percent of total carbohydrate Ratio

$\begin{array}{cccc}\text { Glucose }[G] & \text { Fructose }[F] & \text { Sucrose } & G / F \\ (\text { mean } \pm S E) & (\text { mean } \pm S E) & (\text { mean } \pm S E) & (\text { mean } \pm S E)\end{array}$

$\begin{array}{lllllll}\text { B rapa } & n & 3 & 52.15^{\mathrm{a}} \pm 0.33 & 47.52^{\mathrm{a}} \pm 0.16 & 0.338^{\mathrm{a}} \pm 0.169 & 1.098^{\mathrm{a}} \pm 0.011 \\ & 2 n & 4 & 50.22^{\mathrm{a}} \pm 1.42 & 49.56^{\mathrm{a}} \pm 1.35 & 0.226^{\mathrm{a}} \pm 0.094 & 1.018^{\mathrm{a}} \pm 0.058 \\ & 4 n & 4 & 52.68^{\mathrm{a}} \pm 0.14 & 46.62^{\mathrm{a}} \pm 0.49 & 0.664^{\mathrm{a}} \pm 0.405 & 1.130^{\mathrm{a}} \pm 0.015 \\ & & & & & & \\ \text { B napus } & 4 n & 4 & 51.58^{\mathrm{a}} \pm 0.82 & 47.99^{\mathrm{a}} \pm 0.62 & 0.435^{\mathrm{a}} \pm 0.266 & 1.076^{\mathrm{a}} \pm 0.031\end{array}$

Means in columns followed by different letters are significantly different at $P=0.05$, using 2-tailed $t$ tests.

taries were most constant in volume at opposite, lateral sides of the same flower produced the greatest quantities of nectar sugar in $n$ and $4 n$ plants of $B$ rapa and in plants of $B$ napus (fig 8 ). In the former 2 cases, those plants also had the largest average gland sizes, whereas in $B$ napus a plant (No 3) intermediate for gland size had the most equal-sized lateral glands (figs 7,8 ). A consistent feature of these 3 plants bearing constant-sized nectaries in their flowers was their high frequencies ( $B$ rapa: $n: 85 \%, 4 n: 80 \%$; $B$ napus: $95 \%$ ) of gland morphology that resembled a symmetrical, united outgrowth above the short stamen (Davis et al, submitted).

\section{DISCUSSION}

Regardless of ploidy level and species, the solute concentration of nectar collected at 


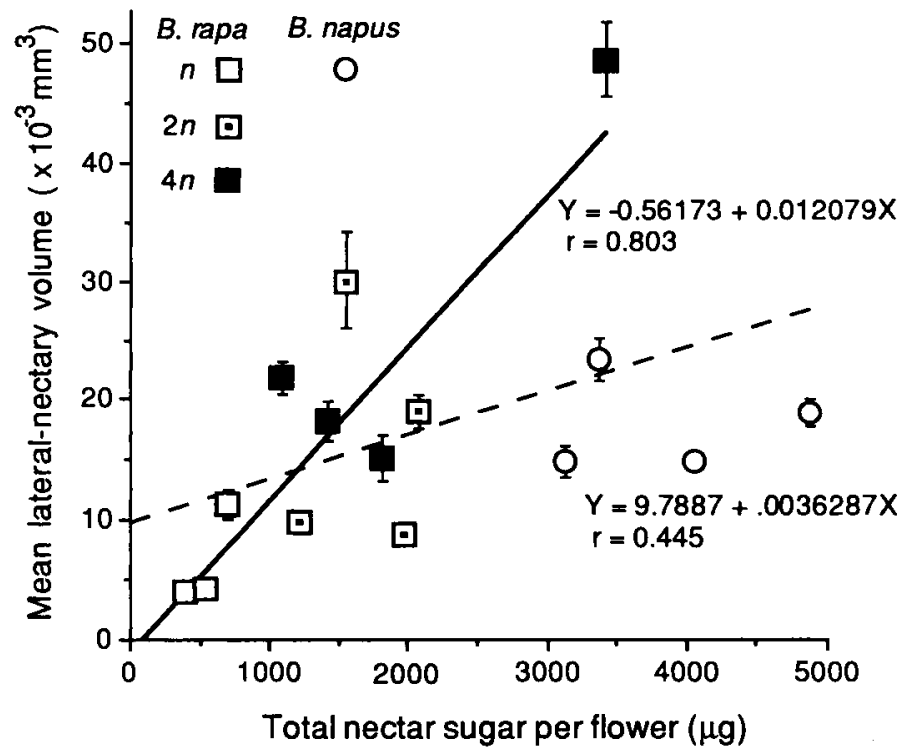

Fig 7. Regression of lateral-nectary size (mean $\pm \mathrm{SE}$ ) on average total nectar carbohydrate per flower, for $B$ rapa (solid line) and for both species (dashed line). Each point represents a plant. $B$ rapa: $n \square$; $2 n \bullet ; 4 n$; $B$ napus $O$.

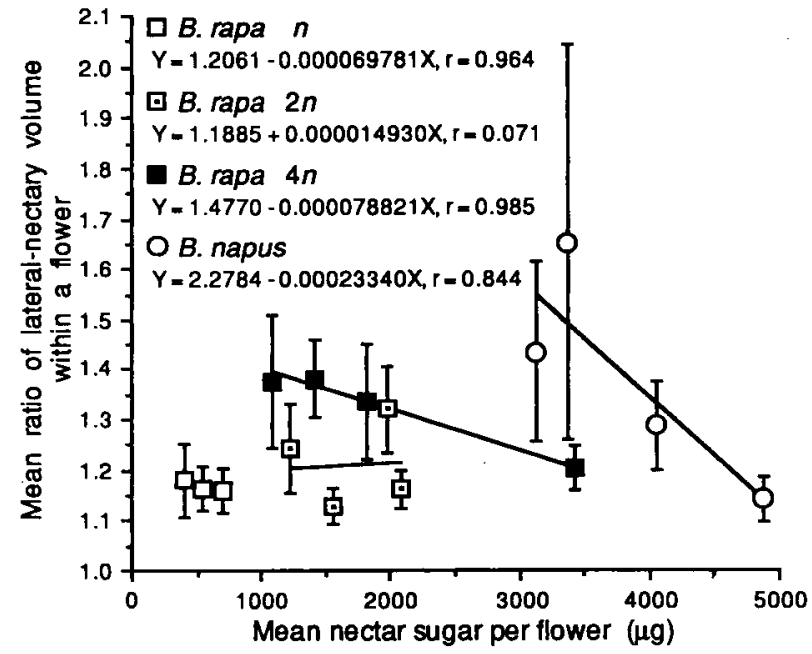

Fig 8. Regression of constancy in size of lateral nectaries within a flower (mean \pm SE) on average total nectar carbohydrate per flower for $n, 2 n$ and $4 n$ plants of $B$ rapa and allotetraploid plants of $B$ napus. $\square B$ rapa $n Y=1.2061-0.000069781 X, r=0.964 ; \square B$ rapa $2 n Y=1.1885+0.000014930 X$, $r=0.071 ; \quad B$ rapa $4 n Y=1.4770-0.000078821 X, r=0.985 ; O B$ napus $Y=2.2784-0.00023340 X$, $r=0.844$. 
the lateral glands was very similar for all the rapid-cycling lines of Brassica. In 12 species studied by Maurizio $(1954,1956)$, however, nectar-carbohydrate concentrations were considerably lower than the present results for Brassica. Furthermore, 8 of 10 species which differed in concentration of nectar solutes had higher concentrations in the $2 n$ than in the $4 n$ state. These discrepancies may be explainable by differences in floral morphology. In the species of Campanulaceae, Fabaceae, Lamiaceae and Solanaceae that Maurizio studied, the base of the corolla is united and tubular. Therefore, nectar accumulating at the base of those flowers is enclosed and relatively protected from the atmosphere, such that evaporation of water from nectar would be reduced. Furthermore, in red clover, the corolla tube in $4 n$ plants is commonly longer than in $2 n$ plants (Paatela, 1962; Valle et al, 1962; Skirde, 1963; Bond, 1968), and the solute concentration of nectar for diploids is similar (Skirde, 1963) or, usually, higher (Maurizio, 1954; Paatela, 1962; Valle et al, 1962; Eriksson, 1979). However, for $B$ rapa, because the corolla is not fused into a tube, increases in petal length associated with higher ploidy (Davis et al, submitted) have little influence on nectar concentration; the nectar droplets still remain exposed at the flower base. Indeed, in this species, nectar of mutant flowers completely lacking petals had the same solute concentration as nectar from petalled flowers (Brunel et al, 1994).

That the concentration of nectar solutes at the lateral glands was similar for all rapidcycling lines of Brassica, and presumably also for the haploid plants, indicates that the great disparity in total quantity of nectar carbohydrates between $B$ napus and the 3 ploidy lines of $B$ rapa resulted from larger volumes of nectar being secreted. This was manifested in the larger number of wicks required to gather the nectar from flowers of $B$ napus, and corroborates the field-plot study of Szabo (1982) in which, on average, flowers of many lines of $B$ napus yielded 2.1 times as much nectar as $B$ rapa (2n). Particularly noteworthy is that this disparity in quantity of nectar carbohydrate is maintained despite numerous competing 'sinks' (the expanding siliques) located below nectar-bearing flowers of $B$ napus. On the contrary, capsules of the self-unfruitful $B$ rapa rarely developed in this controlled, pollinator-free, study environment (Davis et al, submitted).

In $B$ rapa, $4 n$ plants, on average, produced 1.13 times more nectar carbohydrate than $2 n$ plants, but this difference was not significant. Because the solute concentrations of their collected nectars were identical, the $2 n$ and $4 n$ plants probably produced similar nectar volumes. This result disagrees with every previous study, wherein nectar volumes in flowers of $4 n$ plants were usually double or more, that of their $2 n$ counterparts (Maurizio, 1954, 1956; Paatela, 1962; Valle et al, 1962; Skirde, 1963; Eriksson, 1979). Again, increases in length of the corolla tubes of $4 n$ over $2 n$ plants would probably reduce post-secretion evaporation of water from nectar, and therefore contribute to higher nectar volumes (and lower carbohydrate concentrations) in $4 n$ plants. However, estimated total carbohydrate in nectar (product of volume and concentration) in $4 n$ plants was always found to outyield the $2 n$ plants, as follows: Datura spp: 2.65 times; Lobelia sp: 1.29; Monarda sp: 2.33; Nicotiana spp: 1.90; Salvia spp: 1.94; Trifolium hybridum: 2.73; T pratense: 1.98; other Trifolium spp: 2.34. Although $4 n$ plants of $B$ rapa did not outyield the $2 n$ plants significantly, they released 3.53 times more nectar carbohydrate than the $n$ plants.

Whereas the median pair of glands was usually active, though apparently less so in haploids, it produced only small quantities of nectar, such that $95 \%$ of the total nectar carbohydrate per flower from Brassica plants of different ploidy was secreted by the lateral 
nectaries (see Búrguez and Corbet, 1991). These results are consistent with the great disparity in quantity of phloem which supplies each gland type in $B$ arvensis (Frei, $1955)$ and the species studied here, $B$ napus (Frei, 1955; Davis et al, 1986) and $B$ rapa (present results). The heavily secreting lateral nectaries are penetrated by numerous, branching sieve elements whereas the base of the larger, median nectaries lacks any vascular supply or is barely innervated by phloem. Therefore, the large differences in nectar-carbohydrate yields observed overall between $B$ napus and the 3 ploidy levels of $B$ rapa are attributable to differences in production capacity of the lateral nectaries.

Size of the lateral nectaries was not the only significant factor responsible for differences in nectar-carbohydrate production. Haploid plants of $B$ rapa had glands only one-third of the size, and only produced $14 \%$ of the quantity of nectar carbohydrate of plants of $B$ napus. However, the lateral nectaries of $2 n$ and $4 n$ plants of $B$ rapa were no smaller than the corresponding glands of $B$ napus, yet yielded only half as much carbohydrate. Therefore, the absolute size of the glands is not the prime factor. Future research on other nectary features is warranted and might assist selection for high nectar-carbohydrate production, as there can be considerable variation in sugar yield between plants within each ploidy level.

However, plants having a relatively constant size of lateral nectaries at opposite sides of the same flower did tend to produce more nectar carbohydrate. Attainable nectary size may be determined by the symmetry of the floral apex, and the size of other floral parts, because, in terms of floral ontogeny in the Brassicaceae, development of the nectaries occurs last (Sattler, 1973; Davis, 1992). Although nectaries were not investigated in earlier studies of ploidy, glands of $4 n$ plants of all other species previously studied occur on the gynoecium or between it and the androecium, and thus are probably not spatially restricted by neighbouring floral organs to the extent that occurs at the lateral positions in $B$ rapa. In the $4 n$ plants of $B$ rapa, the lower percentage of flower dry weight accounted for by nectar itself may indeed reflect a subnormal increase in lateral nectary size (and function) relative to the size of petals, sepals, etc, compared to the diploids of $B$ rapa.

Maurizio $(1954,1956)$ found that, within a species, the carbohydrate composition in the nectar of polyploid plants differed from $2 n$ plants; the ratio of sucrose to hexose was usually higher in the latter. However, sucrose was virtually absent from the nectar of $n, 2 n$ and $4 n$ plants of $B$ rapa and from $B$ napus, and the overall ratio of glucose to fructose (approx 1.1 to 1) remained constant, regardless of ploidy level. This ratio accords with earlier reports involving analysis of the floral nectar of these same species (Low et al, 1988; Mesquida et al, 1988; Kevan et al, 1991). Thus, at least in nectaries of $B$ rapa, there appear to be similar biochemical systems in operation, regardless of ploidy.

\section{ACKNOWLEDGMENTS}

We thank A Ferrie for generously allowing access to the haploid plants of $B$ rapa, and $P$ Williams for seed of the rapid-cycling lines. $W$ South and $A$ Shukla are thanked for providing a most helpful introduction to HPLC. The careful assistance of S Stone with critical-point drying most of the tissues, and the technical expertise of $Y$ Yano with SEM, are gratefully acknowledged. J Smith, J Sullivan and M Cowell cared for the plants. ARD is grateful to the Natural Sciences and Engineering Research Council of Canada for a Postdoctoral Fellowship.

Résumé - Sécrétion nectarifère des fleurs et ploïdie chez Brassica rapa et $B$ 
napus (Brassicaceae). I. Taille des nectaires, étude quantitative et qualitative des glucides du nectar. On a comparé des lignées haploïdes $(n=10)$, diploïdes $(2 n=20)$ et tétraploïdes $(4 n=40)$ de Brassica rapa (syn campestris) et allotétraploïdes $(4 n=38)$ de $B$ napus pour savoir si la ploïdie pouvait avoir une influence sur la sécrétion nectarifère. Excepté les haploïdes, qui étaient issues d'une culture de microspore, toutes les lignées provenaient de graines de formes de Brassica à cycle rapide. Toutes les plantes, indépendamment du niveau de ploïdie, portaient des nectaires fonctionnels, chaque fleur en possédant 2 paires. Chaque glande latérale (intérieure) est située au-dessus du point d'insertion d'une étamine courte et entourée par la base de 2 étamines longues et de 2 pétales (fig 1, centre). Chaque glande médiane (extérieure) se trouve à la jonction externe de 2 étamines longues (figs 1, 4, 5). Le nectar a été prélevé $24 \mathrm{~h}$ après l'anthèse dans 18 à 22 fleurs par plante. Quatre plantes par niveau de ploïdie ont été étudiées, seulement 3 pour les haploïdes. Dans les lignées à cycle rapide plus de $94 \%$ des glandes médianes ont produit du nectar, que l'on pouvait récolter à l'aide de bandelettes en papier filtre; chez les haploïdes, ce pourcentage était inférieur de plus de la moitié. Néanmoins, dans l'ensemble, les nectaires médians n'ont produit que $5 \%$ de la quantité totale des glucides du nectar floral, la paire latérale en fournissant la majeure partie (tableau I). Cette disparité dans la production de glucides a une raison anatomique : seuls les nectaires latéraux sont directement approvisionnés en phloème (figs 2 et 3 ), les grandes glandes médianes étant dépourvues de vaisseaux (figs 4 et 5). Au sein de chaque niveau de ploïdie, la quantité totale de glucides du nectar produite variait d'une plante à l'autre et l'occasion se présente donc d'exercer une sélection. Les haploïdes n'ont produit que $30 \%$ de la quantité de glucides secrétée par fleur chez les lignées $2 n$ et $4 n$ de $B$ rapa, qui eux-mêmes n'ont secrété que 44 à $50 \%$ de la quantité moyenne produite par $B$ napus (tableau I). Parce que la concentration moyenne du nectar secrété par les nectaires latéraux est semblable chez toutes les lignées à cycle rapide (> $1 \mathrm{~g} / \mathrm{ml}$; tableau II), on attribue ces différences à la disparité dans les volumes de nectar sécrétés. La taille des nectaires latéraux, qui produisent $95 \%$ des glucides du nectar floral, a été estimée sur 20 glandes (10 fleurs) par plante par microscopie électronique à balayage. Une régression linéaire $(r=0,803)$ de la taille moyenne des nectaires latéraux sur la teneur totale moyenne en glucides du nectar a été déterminée pour toutes les plantes de $B$ rapa, mais sa valeur a changé $(r=0,445)$ lorsque les données de $B$ napus ont été incluses. Au total, les plantes fournissant le plus de glucides du nectar ont un pourcentage élevé ( $80-95 \%)$ de glandes latérales uniformes, symétriques (fig 1) et de taille constante pour une même fleur (fig 8 ). Cette relation n'est pas valable pour les plantes $2 n$ de $B$ rapa (fig 8 ). L'analyse par chromatographie liquide à haute pression a montré que les glucides du nectar floral étaient principalement constitués de glucose et de fructose dans le rapport approximatif de 1,1 à 1 , avec une très petite quantité de saccharose (tableau III). La composition en glucides reste constante pour toutes les combinaisons d'espèces et de ploïdie (tableau III).

\section{Brassica rapa / Brassica napus / nectar / glucide / nectaire / ploïdie}

\section{Zusammenfassung - Florale Nektarse- kretion und Ploidie bei Brassica rapa und $B$ napus (Brassicaceae). II. Grösse der Nektarien, Produktion und Zusammen- setzung der Nektar-Kohlenhydrate. Zur Untersuchung des Einflusses der Ploidie auf die Nektarproduktion wurden haploide $(n=10)$, diploide $(2 n=20)$ und tetraploide $(4 n=40)$ Linien von Brassica rapa, sowie}


allotetraploide $(4 n=38)$ Pflanzen von $B$ napus verglichen. Außer der haploiden Linie, die aus einer Mikrosporenkultur stammte, hatten alle Linien kurze Entwicklungszeiten. Alle Pflanzen wiesen unabhängig von ihrem Ploidiegrad funktionale Nektarien auf. Im typischen Fall hatte jede Blüte zwei Nektarienpaare. Die lateralen, innenständigen Drüsen befanden sich oberhalb der Anheftungsstelle eines kurzen Staubblattes (Abb 1, Mitte). Sie wurden von den Basen zweier langer Staubblätter sowie zweier Blütenblätter eingefasst. Die medianen, außenständigen Drüsen befanden sich an der äußeren Verbindungsstelle von zwei langen Staubblättern (Abb 1, 4, 5). Der Nektar wurde 24 Stunden nach Blühbeginn aus 18-22 Blüten pro Pflanze gesammelt. Für jeden Ploidiegrad wurden von den haploiden 3, von den anderen zumeist 4 Pflanzen untersucht. In den Linien mit kurzen Entwicklungszeiten produzierten über $94 \%$ der medianen Drüsen Nekar, der mit Filterpapierdochten eingesammelt werden konnte; bei den haploiden betrug der Prozentsatz weniger als die Hälfte. Insgesamt produzierten die medianen Nektarien durchgehend nur 5\% des Nektarzuckers der Blüte, die überwiegende Menge wurde von dem lateralen Paar erzeugt (Tabelle I). Eine unterschiedliche Produktion von Nektarkohlenhydraten wurde durch anatomischen Befunde untermauert. Nur die lateralen Nektarien wurden direkt von Phloem versorgt (Abb 2, 3), während die grossen medianen Drüsen keine Gefäßversorgung aufwiesen (Abb 4, 5). Innerhalb jedes Ploidiegrades unterschieden sich die Gesamtmengen der Kohlenwasserstoffe (Abb 6), hierdurch bietet sich die Möglichkeit zur Selektion. Haploide Pflanzen von $B$ rapa produzierten im Vergleich zu den $2 n$ und $4 n$ Linien nur $30 \%$ Nektarzucker pro Blüte. Die $2 n$ und $4 n$ Linien erzeugten wiederum nur $44-50 \%$ der mittleren Zuckermenge von $B$ napus (Tabelle I). Da die Konzentration des Nektars der seitlichen Nektarien bei allen raschentwickelnden Linien ähnlich war (höher als
$1 \mathrm{~g} / \mathrm{ml}$; Tabelle II), werden die unterschiedlichen Kohlenhydratmengen auf Unterschiede in den erzeugten Nektarmengen zurückgeführt. Die Größe der lateralen Nektarien, die $95 \%$ der Nektar-Kohlenhydrate produzieren, wurde bei 20 Nektarien (10 Blüten) durch Rasterelektronenmikroskopie bestimmt. Eine lineare Regression des Größendurchschnitts der lateralen Nektarien auf die mittleren Kohlenhydratmengen pro Blüte wurde für alle Pflanzen von $B$ rapa bestimmt ( $r=0,803$; Abb 7). Diese änderte sich jedoch, wenn die Daten von $B$ napus eingeschlossen wurden ( $r=0,445 ;$ Abb 7$)$. Im ganzen gesehen hatten die Pflanzen mit der höchsten Zuckerproduktion einen hohen Prozentsatz (80-95\%) von einheitlichen, symmetrischen (Abb 1) und gleichmäßig großen lateralen Nektarien (Abb 8). Diese Beziehung traf dagegen nicht für die $2 n$ Pflanzen von $B$ rapa (Abb 8) zu. Die Analyse mit Hochdruckflüssigkeitschromatographie ergab, daß die Nektar-Kohlenhydrate überwiegend aus Glukose und Fruktose im Verhältnis von 1,1 zu 1 bestanden. Saccharose war in geringen Mengen vorhanden (Tabelle III). Diese Zusammensetzung war bei allen Ploidiegraden und Arten gleich (Tabelle III).

Brassica rapa / Brassica napus / Nektar / Kohlenhydrate / Nektarium / Ploidie

\section{REFERENCES}

Bolten AB, Feinsinger P, Baker HG, Baker I (1979) On the calculation of sugar concentration in flower nectar. Oecologia (Berl) 41, 301-304

Bond DA (1968) Variation between tetraploid red clover plants in corolla tube length and height of nectar. $J$ Agric Sci Camb 71, 113-116

Brunel E, Mesquida J, Renard M, Tanguy X (1994) Répartition de l'entomofaune pollinisatrice sur des fleurs de colza (Brassica napus $L$ ) et de navette (Brassica campestris L) : incidence due caractère apétale de la navette. Apidologie 25, 12-20

Búrquez A, Corbet SA (1991) Do flowers reabsorb nectar? Funct Ecol 5, 369-379 
Clemente Munoz M, Hernandez Bermejo JE (1978) El aparato nectarigeno en la tribu Brassiceae (Cruciferae). An Jard Bot Madrid 35, 279-296

Cocucci AA, Galetto L (1992) Estudios sobre la estructura del nectario y el sindrome floral en Nicotiana (Solanaceae). Darwiniana 31, 151-157

Crane E (1975) Honey - A Comprehensive Survey. William Heinemann Lid, London, UK

Davis AR (1992) Physiological and structural aspects of floral nectar secretion. Ph D thesis, The Australian National University, Canberra, Australia

Davis AR, Gunning BES (1992) The modified stomata of the floral nectary of Vicia faba $L 1$. Development, anatomy and ultrastructure. Protoplasma 166, 134152

Davis AR, Peterson RL, Shuel RW (1986) Anatomy and vasculature of the floral nectaries of Brassica napus (Brassicaceae). Can J Bot 64, 2508-2516

Eisikowitch D (1981) Some aspects of pollination of oilseed rape (Brassica napus L). J Agric Sci Camb 96 , 321-326

Eriksson M (1979) Nectar production of different cultivars of red clover. Swed J Agric Res 9, 107-112

Frei E (1955) Die Innervierung der floralen Nektarien dikotyler Pflanzenfamilien. Ber Schweiz Bot Gesell $65,60-114$

Fries I, Stark J (1983) Measuring the importance of honeybees in rape seed production. J Apic Res 22, 272 276

Fussell M (1992) Diurnal patterns of bee activity, flowering, and nectar reward per flower in tetraploid red clover. N ZJ Agric Res 35, 151-156

Kevan PG, Lee H, Shuel RW (1991) Sugar ratios in nectars of varieties of canola (Brassica napus). $J$ Apic Res 30, 99-102

Low NH, Nelson DL, Sporns P (1988) Carbohydrate analysis of Western Canadian honeys and their nectar sources to determine the origin of honey oligosaccharides. J Apic Res 27, 245-251

Maurizio A (1954) Untersuchungen über die Nektarsekretion einiger polyploider Kulturpflanzen. Arch Julius Klaus-Stiftung 29, 340-346
Maurizio A (1956) Nouvelles recherches sur la sécrétion nectarifère de plantes cultivées polyploïdes: Nicotiana. Tenth Int Congr Entomol, Montreal, Canada, 4, 1025

McKenna M, Thomson JD (1988) A technique for sampling and measuring small amounts of floral nectar. Ecology 69, 1036-1037

Mesquida J, Marilleau R, Pham-Delègue MH, Renard $M$ (1988) A study of rapeseed (Brassica napus $L$ var oleifera Metzger) flower nectar secretions. Apidologie 19, 307-318

Mohr NA, Jay SC (1988) Nectar- and pollen-collecting behaviour of honeybees on canola (Brassica campestris $L$ and Brassica napus $L$ ). J Apic Res 27, 131-136

Murrell DC, Nash WT (1981) Nectar secretion by toria (Brassica campestris L var toria) and foraging behaviour of three Apis species on toria in Bangladesh. J Apic Res 20, 34-38

Norris $T$ (1941) Torus anatomy and nectary characteristics as phylogenetic criteria in the Rhoeadales. $A m$ JBot 28, 101-113

Paatela J (1962) Characteristics of some diploid and tetraploid varieties of the late red clover Trifolium pratense v subnudum subv serotinum. Acta Agric Fenn 99, 1-31

Sattler R (1973) Organogenesis of flowers - A Photographic Text-Atlas. University of Toronto Press, Toronto, Canada, 68-71

Skirde W (1963) Morphologische und sekretorische Untersuchungen an di- und tetraploidem Klee. Ann Agric Fenn 2, 73-90

Szabo T I (1982) Nectar secretion by 28 varieties and breeder's lines of two species of rapeseed (Brassica napus and B campestris). Am Bee J 122, 645647

Valle O, Sarisalo M, Paatela J (1962) Pollination studies on red clover in Finland. Medd Sverig Fröod Förbl 7 , 98-105

Williams IH (1985) The pollination of swede rape (Brassica napus $\mathrm{L}$ ). Bee World 66, 16-22

Williams PH, Hill CB (1986) Rapid-cycling populations of Brassica. Science 232, 1385-1389 